\title{
Dampak Pembelajaran Daring Selama Pandemi Covid-19 terhadap Psikologis Mahasiswa Keperawatan
}

\author{
Jassica Friscillia Naibaho ${ }^{1}$, Denny Ricky ${ }^{2}$ \\ Fakultas IImu Keperawatan, Universitas Advent Indonesia ${ }^{1,2}$ \\ Email:
}

Riwayat artikel: submit: 6 September 2021 ; revisi: 25 September 2021, diterima: 30 September 2021

\begin{abstract}
ABSTRAK
Pembelajaran daring yang dilaksanakan selama masa pandemi pada semua tingkat pendidikan banyak menyebabkan adanya dampak psikologis yang terjadi termasuk pada golongan mahasiswa. Artikel ini membahas tentang dampak psikologis yang terjadi pada mahasiswa keperawatan Universitas Advent Indonesia dalam mengikuti pembelajar daring dimasa pandemi covid 19. Penelitian ini bertujuan untuk mengetahui dampak psikologis apa yang terjadi terhadap mahasiswa yang mengikuti pembelajaran daring, agar pembelajaran daring ini tetap efektif dan tujuan pembelajarannya tersampaikan. Kajian ini menggunakan metode kualitatif dengan menggunakan metode koesioner DASS-21 dan dibagikan kepada responden dalam bentuk google form. Responden dalam penelitian ini adalah mahasiswa keperawatan Universitas Advent Indonesia. Hasil penelitian menunjukan bahwa: Dalam masa pembelajaran daring ini terdapat adanya dampak psikologis yang terjadi ialah perubahan stress yaitu kecemasan yang terjadi dengan nilai 9,80\% yang berarti berada pada tingkat kecemasan ringan.

Kata kunci : Pembelajaran daring; mahasiswa/i; dan dampak psikologis
\end{abstract}

\section{ABSTRACT}

Online learning that was carried out during the pandemic at all levels of education caused a lot of psychological impacts, including the student group. This article discusses the psychological impact that occurs on nursing students at the Indonesian Adventist University in participating in online learning during the covid 19 pandemic. This study aims to determine what psychological impact occurs on students who take online learning, so that online learning remains effective and the learning objectives are conveyed. . This study uses a qualitative method using the DASS-21 questionnaire method and is distributed to respondents in the form of a google form. Respondents in this study were nursing students at the Adventist University of Indonesia. The results show that: During this online learning period there is a psychological impact that occurs, namely changes in stress, namely anxiety that occurs with a value of $9.80 \%$ which means that it is at a mild level of anxiety.

Keywords: online learning; student; and psychological impact 
Naibaho, J.F.(2021). Dampak Pembelajaran Daring Selama Pandemi Covid-19 terhadap Psikologis Mahasiswa Keperawatan. Edudikara: Jurnal Pendidikan dan Pembelajaran, 6(3), 211-215.

\section{PENDAHULUAN}

Perkuliahan secara daring terpaksa mengubah sistem tatap muka menjadi perkuliahan jarak jauh daring akibat Pendemi Covid19 yang melanda Indonesia Hal ini menyebabkan pembelajaran yang dilakukan menjadi kurang efisien, peserta didik lebih susah memahami materi yang diberikan dosen, kurangnya interaksi antara dosen dan mahasiswa membuat mereka susah memahami materi yang diberikan, mahasiswa lebih susah menanyakan materi yang belum paham dan kurangnya konsentrasi mahasiswa jika dilakukan pembelajaran secara daring. (Mastuti, 2020).

Stres akademik pada mahasiswa tidak hanya terjadi di Indonesia, penelitian wang menyimpulkan bahwa mahasiswa China menunjukkan kecemasan yang lebih tinggi selama pandemi covid-19 (Wang \& Zhao, 2020).

University dan UIN Bandung menunjukkan sekitar 60,5\% mahasiswa beradaptasi dengan penggunaan teknologi pembelajaran perkuliahan daring tetapi sekitar 59,5\% keberatan akan tugas diberikan dosen yang berakibat tingkat stress mahasiswa sekitar $60 \%$. (Menurut Agus Kusnayat, 2020).

Kuliah daring atau yang biasa disebut dengan sebutan kuliah online adalah proses belajar mengajar berbasis internet yang dilakukan oleh mahasiswa, maupun dosen, dimana peserta dapat mengakses materi, saling berinteraksi,mendiskusikan materi, dan mengembangkan diri lewat pengalaman belajar berbasis online (Universitas Indonesia,2020).

Menurut Erin \& Maharani, (2018) persepsi yang positif akan berhubungan secara linier positif terhadap sikap yang mampu mendorong motivasi belajar. Persepsi ini muncul berdasarkan pengalaman dan perasaan melalui proses pengindraan yang dapat menghasilkanresponpositif atau negatif. Wacana tentang penyelenggaran pembelajaran tahun akademik baru 2020/2021 yang masih akan dilaksanakan secara daring telah didiskusikan, oleh karenanya dibutuhkan panduan yang jelas yang disusun sesuai kondisi dan hasil evaluasi dari pelaksanaan yang sebelumnya.

Sekolah dan universitas sebagai lembaga pendidikan formal tentu harus merespon dan mengambil sikap akan situasi ini dengan tepat. Aktivitas pembelajaran di sekolah dan universitas di seluruh Indonesia dihentikan, sebagaimana tertuang dalam Surat Edaran Mendikbud Nomor 4 Tahun 2020 tentang Pelaksanaan Kebijakan Pendidikan Dalam Masa Darurat (Kossasy, 2020)

\section{METODE}

Penulis artikel ini menggunakan metode kualitatif dengan menggunakan metode koesioner DASS-21 dan dibagikan kepada responden dalam bentuk google form.

Inform consent yang digunakan adalah metode koesioner DASS-21. Setiap responden akan mendapatkan penjelasan tentang penelitian yang diadakan, kemudian responden mengisi informed consent. Dalam mengisi informed consent, jika responden menyetujui maka responden akan mengisi menurut skala yang sudah di tentukan pada kolom yang disediakan. Inform consent ini dibagikan dalam bentuk link kepada setiap responden dan untuk menjawab koesionernya responden bisa membuka link yang sudah di bagikan oleh penulis.

Pengambilan sample menggunakan rumus slovin, yang merupakan salah satu rumus yang umum digunakan dalam bidang statistik, khususnya saat penghitungan data dalam bentuk survey dengan populasi yang relatif besar. Sampel dalam penelitian ini sebanyak 80 responden. Dan menggunakan koesioner DASS-21. 
Naibaho, J.F.(2021). Dampak Pembelajaran Daring Selama Pandemi Covid-19 terhadap Psikologis Mahasiswa Keperawatan. Edudikara: Jurnal Pendidikan dan Pembelajaran, 6(3), 211-215.

HASIL

Tabel 1 menunjukkan data responden yaitu terdapat dua jenis respnden yaitu laki-laki dan perempuan. Jumlah responden yaitu 80 orang diataranya 16 orang lai-laki dan 64 orang perempuan dari tingkat 1-4.

Tabel 2 menjelaskan ada beberapa kategori dari dampak psikologis yang terbagi tiga antara lain ialah stress, kecemasan, depresi. Dapat di lihat pada tabel 2 bahwa terdapat jumah frekuensi dan persentasi stess, kecemasan, dan depresi pada mahasiswa laki-laki maupun wanita. Dan dari tabel terseut dapat kita lihat tingkatan-tingkatan stressnya apakah ringan, sedang, berat, atapun sangat berat.

Tabel 3 menjelaskan bahwa tingkat stres rata-rata berada pada kategori normal (0-14) dengan nilai 12.40, kecemasan berada pada tingkat ringan (8-9) dengan nilai 9.80, dan depresi berada pada tingkat normal (0-9) yaitu dengan nilai 7.35.

Tabel. 1 Distribusi Data Responden

\begin{tabular}{ccc}
\hline & Data Responden & \\
\hline Data & Frekuensi & Persentase (\%) \\
\hline Jenis Kelamin & & \\
\hline Laki-laki & 16 & 20 \\
\hline Perempuan & 64 & 80 \\
\hline Total & $\mathbf{8 0}$ & \\
\hline Tingkat & & 100 \\
\hline I & 10 & 30 \\
\hline II & 24 & 18 \\
\hline III & 14 & 40 \\
\hline IV & 32 & $\mathbf{1 0 0}$
\end{tabular}

Tabel. 2

Hasil Skor DASS 21-Gambaran Tingkat Stres, Kecemasan, dan Depresi Interpretasi Skor DASS 21 Berdasarkan Jenis Kelamin

\begin{tabular}{|c|c|c|c|c|}
\hline Data & Status & Kategori & Frekuensi & Persentase (\%) \\
\hline \multicolumn{5}{|c|}{ Jenis Kelamin } \\
\hline \multirow{15}{*}{ Laki-laki } & \multirow[t]{5}{*}{ Stres } & Normal (0-14) & 10 & 62 \\
\hline & & Ringan (15-18) & 2 & 13 \\
\hline & & Sedang (19-25) & 3 & 19 \\
\hline & & Berat (26-33) & 1 & 6 \\
\hline & & Sangat Berat (34+) & 0 & 0 \\
\hline & & Total & 16 & 100 \\
\hline & \multirow[t]{5}{*}{ Kecemasan } & Normal (0-7) & 10 & 62 \\
\hline & & Ringan (8-9) & 1 & 6 \\
\hline & & Sedang (10-14) & 2 & 13 \\
\hline & & Berat (15-19) & 1 & 6 \\
\hline & & Sangat Berat (20+) & 2 & 13 \\
\hline & \multirow{4}{*}{ Depresi } & Total & 16 & 100 \\
\hline & & Normal (0-9) & 9 & 56 \\
\hline & & Ringan (10-13) & 4 & 25 \\
\hline & & Sedang (14-20) & 1 & 6 \\
\hline
\end{tabular}


Naibaho, J.F.(2021). Dampak Pembelajaran Daring Selama Pandemi Covid-19 terhadap Psikologis Mahasiswa Keperawatan. Edudikara: Jurnal Pendidikan dan Pembelajaran, 6(3), 211-215.

\begin{tabular}{|c|c|c|c|c|}
\hline & & Berat (21-27) & 2 & 13 \\
\hline & & Sangat Berat (28+) & 0 & 0 \\
\hline & & Total & 16 & 100 \\
\hline \multirow{18}{*}{ Perempuan } & \multirow[t]{5}{*}{ Stres } & Normal (0-14) & 39 & 61 \\
\hline & & Ringan (15-18) & 7 & 11 \\
\hline & & Sedang (19-25) & 10 & 16 \\
\hline & & Berat (26-33) & 8 & 12 \\
\hline & & Sangat Berat $(34+)$ & 0 & 0 \\
\hline & \multicolumn{2}{|r|}{ Total } & 64 & 100 \\
\hline & \multirow[t]{5}{*}{ Kecemasan } & Normal (0-7) & 23 & 36 \\
\hline & & Ringan (8-9) & 7 & 11 \\
\hline & & Sedang (10-14) & 16 & 25 \\
\hline & & Berat (15-19) & 13 & 20 \\
\hline & & Sangat Berat $(20+)$ & 5 & 8 \\
\hline & \multirow{6}{*}{ Depresi } & Total & 64 & 100 \\
\hline & & Normal (0-9) & 42 & 66 \\
\hline & & Ringan (10-13) & 11 & 17 \\
\hline & & Sedang (14-20) & 7 & 11 \\
\hline & & Berat (21-27) & 4 & 6 \\
\hline & & Sangat Berat (28+) & 0 & 0 \\
\hline & & Total & 64 & 100 \\
\hline
\end{tabular}

Tabel.3

Hasil Skor DASS 21 Gambaran Tingkat Stres, Kecemasan, dan Depresi

\begin{tabular}{cccc}
\hline \multicolumn{4}{c}{ Descriptive Statistics } \\
\hline N & Mean & Std. Deviation \\
\hline Stres & 80 & 12.40 & 8.476 \\
Kecemasan & 80 & 9.80 & 7.289 \\
Depresi & 80 & 7.35 & 6.450 \\
Valid N (listwise) & 80 & & \\
\hline
\end{tabular}

Di masa pandemik sekarang ini proses belajar mengajar dilakukan secara daring atau pembelajaran jarak jauh. Oleh karena proses pembelajaran daring ini ada bayak dampak yang terjadi antara lain stress, kecemasan, dan depresi. Banyak mahasiswa ataupun kalangan pelajar lain yang merasa jenuh dan bahkan cemas akibat pembelajaran daring.

Faktor yang mempengaruhinya ada beberapa ialah sinyal yang tidak memadai, kebutuhan paket belajar, cara belajar mengajar jarak jauh dan itu semua membuat para mahasiswa mengalami dampak psikologis salah satunya kecemasan. Karena dampak ini pula proses pembelajaran daring terkadang dapat membuat masalah psikologis mahasiswa terganggu dan terdapat kurangnya minat belajar terhadap diri merekamasing-masing.

Faktor yang mempengaruhi aspek psikologi dalam pembelajaran antara lain intelegensi, lingkungan belajar dan metode pembelajaran (Umar, 2002). Intelegensi merupakan suatu kecerdasan. Lingkungan berpengaruh terhadap perkembangan individu. Metode pembelajaran merupakan cara yang digunakan pemberi pembelajaran dalam menjalankan fungsinya dan merupakan alat untuk mencapai tujuan pembelajaran 
Naibaho, J.F.(2021). Dampak Pembelajaran Daring Selama Pandemi Covid-19 terhadap Psikologis Mahasiswa Keperawatan. Edudikara: Jurnal Pendidikan dan Pembelajaran, 6(3), 211-215.

\section{SIMPULAN}

Setelah dilakukan analisis terhadap 80 orang mahasiswa/i keperawatan diambil kesimpulan bahwa di dalam masa pandemik yang menggunakan metode pembelajaran daring ini terdapat dampak psikologis yang dialami mahasiswa/i keperawatan Universitas Advent Indnesia. Tingkat stress rata-rata berada pada kategori nornal(0-14) dengan nilai 12,40 , kecemasan berada pada tingkat ringan (8-9) dengan nilai 9,80, dan depresi berada pada tingkat normal (0-9) yaitu dengan nilai 7,35.

Maka hasil kesimpulan yang diambil yaitu mahasiswa keperawatan Universitas Advent Indonesia menglami kecemasan tingkat ringan nilai 9,80. Walaupun tingkat kecemasannya ringan itu juga penting untuk diperhatikan supaya di proses belajar mengajar metode daring ini tidak mendapatkan dampak yang lebih parah. Maka perlunya bimbingan dari dosen dan juga perhatian dan bimbingan yang lebih dalam proses pembelajaran daring ini. Suupaya mahasiswa/i tidak jenuh dan cemas dalam menghadapi pembelajaran aring di masa pandemik.

\section{REFERENSI}

Erin, \& Maharani, A. (2018). Persepsi Mahasiswa Terhadap Perkuliahan Online

Kusnayat, A. (2020). Pengaruh Teknologi Pembelajaran Kuliah Online di Era Covid19 dan Dampaknya Terhadap Mental Mahasiswa.

Kossasy, 2020. Analisis Tingkat Stres Akademik Pada Mahasiswa Selama Pembelajaran Jarak Jauh Dimasa Covid-19, Medan: Universitas Medan Area, Indonesia. $\begin{array}{clrl}\begin{array}{cl}\text { Mastuti, R. (2020). Teaching From } \\ \text { Belajar. }\end{array} \quad \text { Medan: Yayasan Kita } & \text { Menulis. }\end{array}$

Setyonegoro, R.K. (1991). Anxietas dan Depresi suatu Tinjauan Umum tentang Diagnostik dan Terapi dala, Depresi: Beberapa Pandangan Teori dan Implikasi Praktek di Bidang Kesehatan Jiwa. Jakarta.

Universitas Indonesia (2020). Pengertian Kuliah Daring. $\quad$ Diakses pada 14 Mei 2020

Wang, C., \& Zhao, H. (2020). The Impact of COVID-19 on Anxiety in Chinese University Students. Frontiers in Psychology. 